\title{
高温純水中における鉄鋼材料の腐食と微量金属イオンの析出*
}

\author{
本田卓**, 樫村栄二**, 大橋 健也**, 古谷保 正** \\ ** 株式会社日立製作所日立研究所
}

\section{Corrosion of Ferrous Materials and Deposition of Trace Metal Ions in High Temperature and High Purity Water*}

\author{
Takashi Honda**, Eiji Kashimura**, Kenya Ohashi** \\ and Yasumasa Furutani**
}

**Hitachi, Ltd., Hitachi Research Laboratory

\begin{abstract}
The mechanism of oxide film growth was evaluated for ferrous materials in high temperature and high purity water simulating a boiling water reactor condition. Further, the deposition kinetics of a trace amount of metal ions such as $\mathrm{Co}^{2+}$ was elucidated by XPS, SIMS and other analyses. The films formed on Type 304 stainless steel mainly consisted of spinel type oxides such as magnetite. The release amount of chromium was relatively large compared with iron and nickel. The oxide films grew primarily inward at the oxide/metal interface. Cobalt ions in water were incorporated at the same point and occupy the divalent sites of spinel type oxides. The film growth mechanism of carbon steel was similar to that of stainleess steel, while the release amount of corrosion products from carbon steel was much smaller than that from stainless steel.
\end{abstract}

\section{1. 緒言}

沸騰水型原子炉 (BWR) の配管材料には, ステンレス 鋼と炭素鋼が用いられている。これらの材料表面には腐 食にともなって酸化皮膜が形成されるが, 炉水に含まれ る放射性腐食生成物である ${ }^{60} \mathrm{Co}$ 等の金属イオンはこの 皮膜内に取り込まれ, 配管表面線量率の上昇をもたら す。プラントの円滑な運転には, 表面線量率の低減が望 まれ，これまでに水質及び材料面でさまざまな対策がと られてきた1)。しかし，炉水環境に打ける鉄鋼材料の腐 食と ${ }^{80} \mathrm{Co}$ に代表される微量金属イオンの蓄積挙動につ いては不明な点が多い。

これまでに, 高温純水中での腐食に関しては主に腐食 減量と腐食生成物の放出挙動が調べられて和り2) 6), 酸 化皮膜の形態, 構造及び成長機構に着目した研究例 ${ }^{7)}$ は 少ない。また, 放射性イオンの蓄積挙動は実炉 ${ }^{8) ~ 10) ~ あ ~}$

*第 4 回日ソ腐食セミナー (機械振興会館) で一部 発表

** T319-12 茨城県日立市久慈町 4026 番地 (4026 Kuji-cho, Hitachi-shi, Ibaraki-ken, 319-12 Japan)
るいは RI (Radioisotope) を用いたループ11)での検討 が主で，形成される皮膜に関しては明らかにされていな い部分が多い。そこで, 本研究では 304 ステンレス鋼と 炭素鋼を対象に, BWR 環境に打ける腐食と ${ }^{60} \mathrm{Co}$ イオ ンの蓄積挙動を，酸化皮膜を多角的に分析することによ り明らかにすることを目的とした。

\section{2. 実験方法}

\section{1 模擬忓水浸清実験}

本研究では本来, ${ }^{80} \mathrm{Co}$ の蓄積挙動を明らかにするこ とを目的としているが，酸化皮膜中の化学形態を調べる ために化学的に等価な非放射性のコバルトイオン $\left(\mathrm{Co}^{2+}\right)$ を用いた。供試材には Table 1 の化学組成をも つ 304 鋼（低コバルト材）及び炭素鋼を用いた。低コバ ルト材を用いた理由は，通常の 304 鋼は不純物として $0.2 \sim 0.3 \%$ のコバルトを含んでいるので, 蓄積評価に 及ぼす母材の影響をできるだけ小さくするためである。 なお，コバルトは鋼材を酸溶解した後, フレームレスゼ ーマン原子吸光法により定量した。試験片は $8 \times 30 \times 1$ $\mathrm{mm}$ 及 $8 \times 8 \times 1 \mathrm{~mm}$ の板状に成形後, 表面を\# 1,000 工 
Table 1 Chemical composition of materials used as test specimens. (wt $\%$ )

\begin{tabular}{cccccccccc}
\hline & $\mathrm{C}$ & $\mathrm{Si}$ & $\mathrm{Mn}$ & $\mathrm{P}$ & $\mathrm{S}$ & $\mathrm{Co}$ & $\mathrm{Ni}$ & $\mathrm{Cr}$ \\
\hline SUS 304 & 0.02 & 0.56 & 1.36 & 0.023 & 0.002 & 0.041 & 10.48 & 18.57 \\
Carbon Steel & 0.10 & $<0.01$ & 0.30 & 0.018 & 0.016 & 0.016 & - & - \\
\hline \hline
\end{tabular}

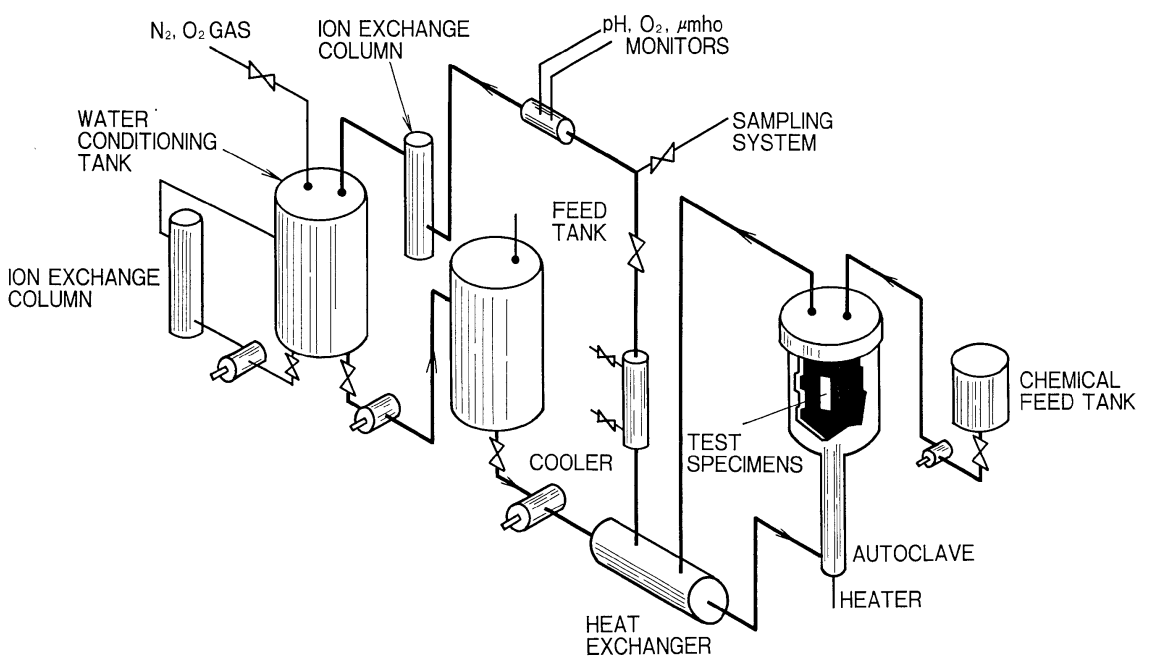

Fig. 1 Schematic diagram of recirculation loop.

メリー紙で研磨し，アセトンで脱脂洗浄して用いた。

Fig. 1 は用いた装置の系統構成を示す。水質調整タン クで溶存酸素濃度 (DO) を $200 \mathrm{ppb}$ に調整した純水 $(<$ $0.1 \mu \mathrm{S} / \mathrm{cm}$ ) を流速 $30 \mathrm{l} / \mathrm{h}$ （線流速 $1 \mathrm{~cm} / \mathrm{s}$ ) で通水した オートクレーブに試験片を浸漬した。温度は再生熱交換 器, 予熱器を用いて $288^{\circ} \mathrm{C}$ に保持した。 $\mathrm{Co}^{2+}$ イオンは 薬注タンクに所定濃度の硫酸コバルトを溶解させ, 薬注 ポンプを用いてオートクレーブ内に連続注入した。試験 時の $\mathrm{Co}^{2+}$ イオン濃度はオートクレーブ下流に設けたサ ンプリングラインを用いて測定したが, 得られた值 (3 $\pm 0.5 \mathrm{ppb})$ は注入量から求めた值とよく一致した。ま た，他の水質值は主ループ内に設置した電導度計， DO 計, $\mathrm{pH}$ 計により連続測定した。

浸漬は $1,000 \mathrm{~h}$ まで行い, 小さい方の試験片は次節に 述べる機器分析に供した。一方, 大きい方の試験片につ いては, 皮膜をカソード電解法 ${ }^{8)}$ により㓦離したのち塩 酸溶液中で加熱溶解し，原子吸光法により，304 鋼では 鉄, クロム, ニッケルの, また，炭素鋼では鉄の量を求 めた。なお, 腐食減量は浸漬前と浸漬後に皮膜を剥離し たのちの試験片の重量差から，また酸化皮膜量は皮膜剝 離前後の重量差から, さらに腐食生成物の放出量は腐食 減量と原子吸光法により求めた皮膜中の金属元素の総量 との差から求めた。

\section{2 酸化皮膜の分析}

前節で形成した酸化皮膜は走査型電子顕微鏡 (SEM), $\mathrm{X}$ 線回折法, 2 次イオン質量分析法 (SIMS) 及びX線光 電子分光法 (XPS) により調べた。SIMS は 1 次イオン に $10 \mathrm{kV}$ のアルゴンイオン $\left(\mathrm{Ar}^{+}\right)$を用い, 電流密度は $960 \mathrm{~mA} / \mathrm{m}^{2}$, ビーム径を $400 \mu \mathrm{m}$, サンプル室の真空度を $7 \times 10^{-7}$ Torr に設定し, 2 次イオンの加速電圧は $1.5 \mathrm{kV}$ とした。光電子分光器は KRATOS 製, XSAM-800 型 で，イオン化源には $\mathrm{MgK}_{\alpha}$ 線 $(1,253.6 \mathrm{eV})$ を用いた。 XPS スペクトルの測定に括いては必要な光電子の運動 エネルギーの範囲を $20 \mathrm{eV} / \mathrm{min}$ で 10 回走査し, カウン ト数の積算值をスペクトルとして描かせた。試料室の真 空度は $1 \times 10^{-9}$ Torr, 温度は室温である。構成元素を分 析する場合, コバルト，鉄，クロム，ニッケルについて は $2 \mathrm{p}_{3 / 2}$ スペクトルを, 酸素及び炭素については $1 \mathrm{~s}$ ス ペクトルを測定した。本装置の測定エネルギーは, C 1s の結合エネルギー $(\mathrm{Eb})$ を $285.0 \mathrm{eV}$ として他のピーク の $\mathrm{Eb}$ 值を補正した。また，アルゴンスパッタリングは $3 \mathrm{kV}, 16 \mathrm{~mA} / \mathrm{m}^{2}$ で 2 210 $\mathrm{min}$ 行った。

\section{3. 結 果}

\subsection{4 鋼及び炭素鋼の腐食挙動}

304 鋼及び炭素鋼に梪ける皮膜の成長は Fig. 2 亿示 
Table 2 Corrosion behavior of Type 304 stainless and carbon steels exposed for $1,000 \mathrm{~h}$ at $288^{\circ} \mathrm{C}$.

$$
\left(\mathrm{g} \cdot \mathrm{m}^{-2}\right)
$$

\begin{tabular}{lllll}
\hline \hline & SUS 304 & Carbon Steel \\
\hline Corrosion & 1.80 & $(100 \%)$ & 7.02 & $(100 \%)$ \\
Oxide Films & 1.59 & $(88 \%)$ & 6.95 & $(99 \%)$ \\
Release & 0.21 & $(12 \%)$ & 0.07 & $(1 \%)$ \\
\hline \hline
\end{tabular}

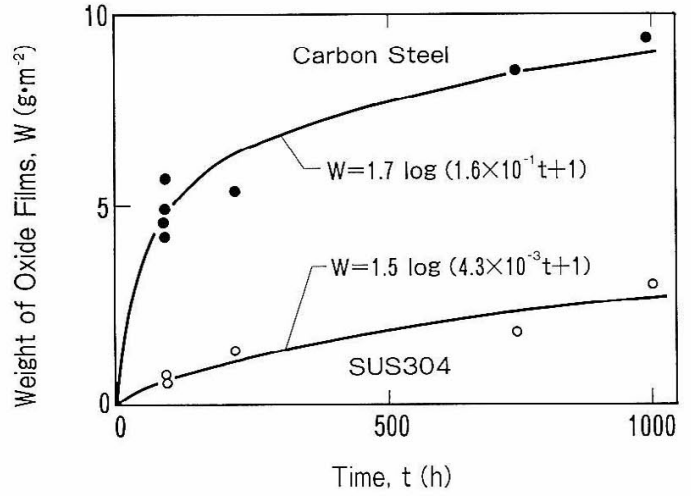

Fig. 2 Growth of oxide films on Type 304 stainless and carbon steels exposed at $288^{\circ} \mathrm{C}$.

すように，それぞれ (1) 及び (2) 式で表される対数則に よく従っていた。な拈，Wは酸化皮膜量 $\left(\mathrm{g} / \mathrm{m}^{2}\right), t$ は浸 漬時間 $(\mathrm{h}), \sigma$ は標準偏差 $\left(\mathrm{g} / \mathrm{m}^{2}\right)$ である。

$$
\begin{aligned}
& W=1.5 \log (0.0043 t+1) ; \sigma=0.26 \\
& W=1.7 \log (0.16 t+1) ; \sigma=0.65
\end{aligned}
$$

Table 2 は 1,000 h 浸漬後の 304 鋼と炭素鋼を対象に, 腐食娍量 (Corrosion), 酸化皮膜量 (Oxide Films) 及び 腐食生成物の水中への放出量 (Release) を調べた結果で ある。304 鋼では腐食に関与した金属元素のうち $88 \%$ が皮膜を形成し，12\%が水中に放出している。一方，炭 素鎘では 99\% が皮膜として残り，放出率はわずかに 1\%であった。この放出率の差は次章で詳述するが, 304 銿ではクロムの溶出が大きいものと考觉られる。

\subsection{4 鋼の酸化皮膜}

Fig. 3 は 304 鋼を模擬炉水中に 1,000 h 浸漬したのb に形成した酸化皮膜の SEM 観察結果である。粒径約 1 $\mu \mathrm{m}$ 以下の微細な結唱粒が表面をお゙抽っている。 X 線回 折では $\mathrm{Fe}_{3} \mathrm{O}_{4}$ を主体とするスピネル型酸化物が主に検 出され， $\alpha-\mathrm{Fe}_{2} \mathrm{O}_{3}$ 峳量であった。

Fig. 4 は $\mathrm{Co}^{2+}$ イオンを $3 \mathrm{ppb}$ 溶存する $288^{\circ} \mathrm{C}$ の高 温純水中に 304 鋼を $1,000 \mathrm{~h}$ 浸漬した後に, SIMSによ り皮膜深さ方向に和りる元素分布を調べた結果を示す。 酸素の分布から皮膜/金属界面の位置 $(\mathrm{I} / \mathrm{m})$ が，スパッ

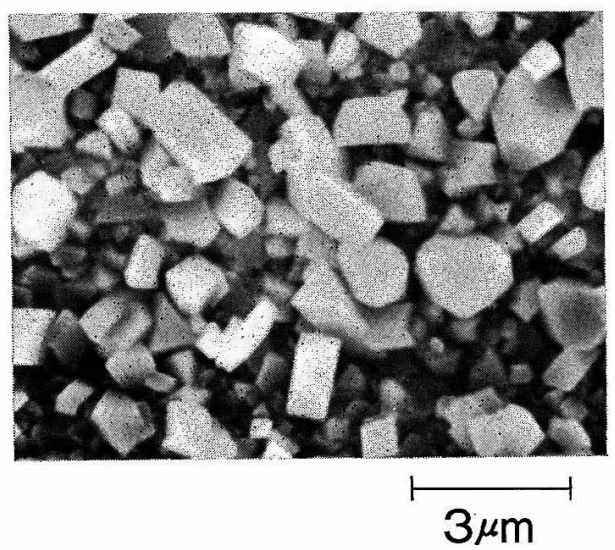

Fig. 3 Scanning electron micrograph of oxide films formed on Type 304 stainless steel exposed for $1000 \mathrm{~h}$ at $288^{\circ} \mathrm{C}$.

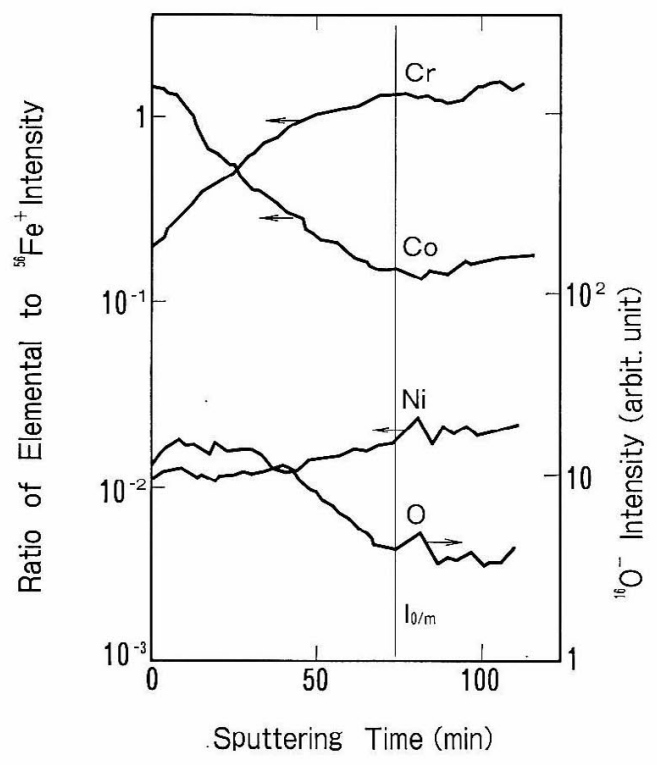

Fig. 4 Depth concentration profile of elements in oxide films on Type 304 stainless steel exposed for $1,000 \mathrm{~h}$ at $288^{\circ} \mathrm{C}$. 
Table 3 Concentration ratio of elemental metals in oxide films on Type 304 stainless steel exposed for $1,000 \mathrm{~h}$ at $288^{\circ} \mathrm{C}$.

\begin{tabular}{lcc}
\hline & Oxide Films & Steel \\
\hline $\mathrm{Cr} / \mathrm{Fe}$ & 0.093 & 0.27 \\
$\mathrm{Ni} / \mathrm{Fe}$ & 0.13 & 0.15 \\
$\mathrm{Co} / \mathrm{Fe}$ & 0.045 & 0.00059 \\
\hline
\end{tabular}

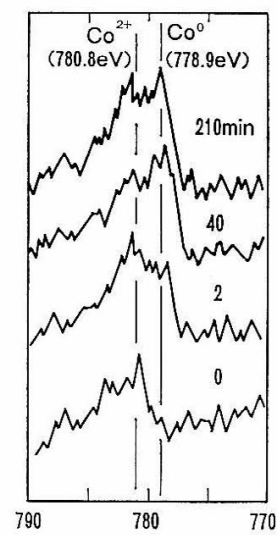

(a)

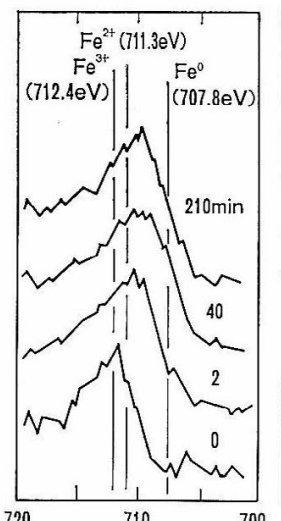

Binding Energy (eV)

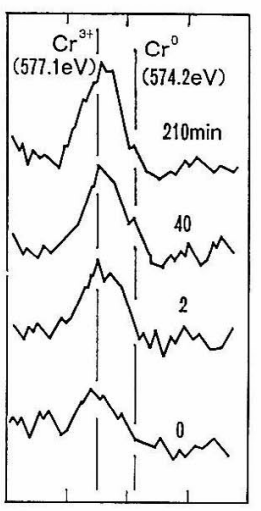

(c)

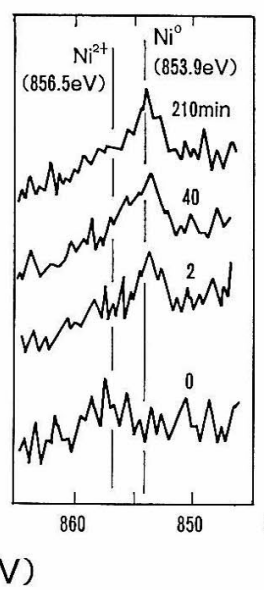

(d)

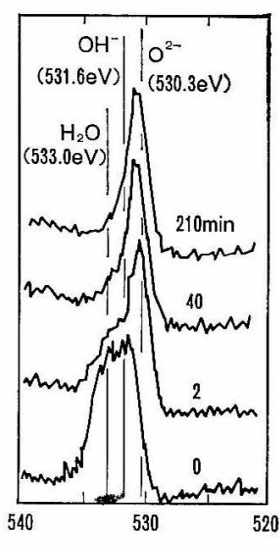

(e)

Fig. 5 XPS spectra of $2 \mathrm{p}_{3 / 2}$ level of $\mathrm{Co}, \mathrm{Fe}, \mathrm{Cr}, \mathrm{Ni}$ and $1 \mathrm{~s}$ level of $\mathrm{O}$ for oxide films on Type 304 stainless steel exposed for $1,000 \mathrm{~h}$ at $288^{\circ} \mathrm{C}$, $\mathrm{Ar}^{+}$sputtering time 0-210 min; (a) Co, (b) $\mathrm{Fe}$, (c) $\mathrm{Cr}$, (d) $\mathrm{Ni}$, (e) $\mathrm{O}$.

タリング時間で $75 \mathrm{~min}$ 程度にあることがわかる。クロ ムは斗膜表面方向に濃度が単調減少している。ニッッル も同じ現象がみるれるが，クロムに比べると減少程度は 小さい。一方，コバル卜は，逆に皮膜内方向に減少する 傾向を示した。また, Table 3 Kクロム, ニッケル及び コバルトの鉄に対する濃度比を皮膜と母材で比較した。 クロムは皮膜中で母材に比べると約 3 分の 1 に減少して いるが, ニッケルは10\% 位の減少にすぎない。また，コ バルトは逆に皮膜中で 2 胡近く増加している。Fig. 5 はXPSにより皮膜の深さ方向に和ける各元素の存在形 態を分析した結果である。Co $2 \mathrm{p}_{3 / 2}$ はスパッタリングを 行わない皮膜最外表面では $781 \mathrm{eV}$ 付近に単一ピークを 認めたが，スパッタリングにともない $779 \mathrm{eV}$ 付近に新 たなピークが現れた。Fe $2 \mathrm{p}_{3 / 2}$ は最外表面では $712 \mathrm{eV}$ 付近に単一ピークを認めたが，スパッタリングにとるな い低エネルギー側にピーク位置がシフトした。Cr $2 \mathrm{p}_{3 / 2}$ はスパッタリングによらず $577 \mathrm{eV}$ 付近に単一ピークが 存在した。 $\mathrm{Ni} 2 \mathrm{p}_{3 / 2}$ は計数感度が悪いが，最外表面では $857 \mathrm{eV}$ 付近に, またスパッタリング後は $854 \mathrm{eV}$ 付近に ピークがみられた。O $1 \mathrm{~s}$ は最外表面では $532 \sim 533 \mathrm{eV}$

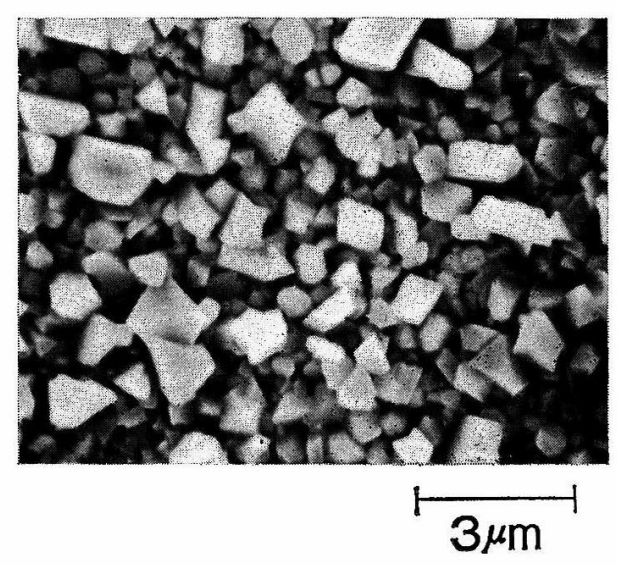

Fig. 6 Scanning electron micrograph of oxide films formed on carbon steel exposed for $1,000 \mathrm{~h}$ at $288^{\circ} \mathrm{C}$.

にブロードなピークがある。 $2 \mathrm{~min}$ スパッタリングした のちには, $530 \mathrm{eV}$ 付近にシャープなピークを認めたが, 高エネルギー側に肩状ピークを残している。40 min 以 上のスパッタリングにより肩状のピークは消え, ピーク 


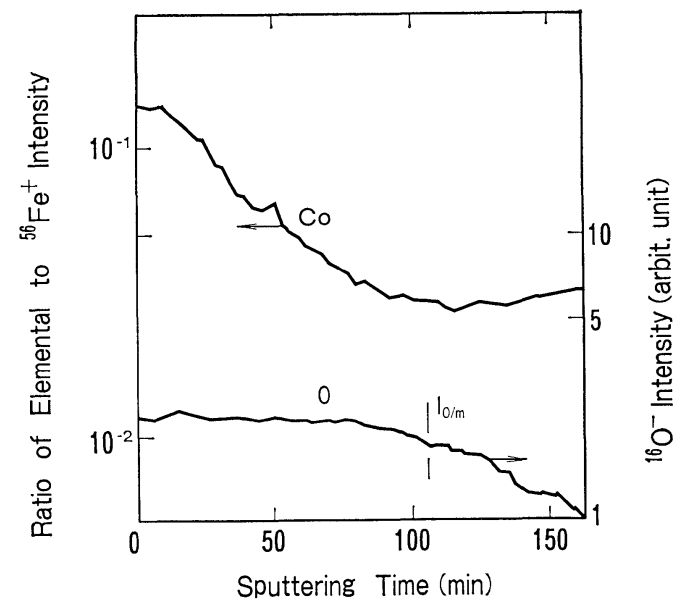

Fig. 7 Depth concentration profiles of elements in oxide films on carbon steel exposed for $1,000 \mathrm{~h}$ at $288^{\circ} \mathrm{C}$.

\section{位置はわずかに低エネルギー側にシフトした。}

\section{3 炭素鋼の酸化皮膜}

次に 304 鋼と同じ環境で $1,000 \mathrm{~h}$ 浸漬した炭素鋼の酸 化皮膜について検討した。Fig. 6 はSEM 観察の結果で ある。粒径 $1 \mu \mathrm{m}$ 以下の粒状酸化物が表面を一様に, か つ緻密にお゙おっている。X 線回折により調べたところ, $\mathrm{Fe}_{3} \mathrm{O}_{4}, \alpha-\mathrm{Fe}_{2} \mathrm{O}_{3}$ 及び $\mathrm{CoFe}_{2} \mathrm{O}_{4}$ の存在を認めた。

Fig. 7 は炭素鋼を $1,000 \mathrm{~h}$ 浸漬した後の SIMS による 分析結果を示す。皮膜/金属界面はスパッタリング時間 で $100 \mathrm{~min}$ 程度にあった。コバルトは 304 鋼と同様に
内方向に単調減少した。

次に XPS により皮膜深さ方向でのコバルト，鉄及び 酸素の存在形態を調べた。Fig. 8 はその結果を示す。 Co $2 \mathrm{p}_{3 / 2}$ のスペクトルは皮膜最外表面では計数感度が悪 いが, $781 \mathrm{eV}$ 付近にピークの存在を認めた。スパッタリ ング後は $779 \mathrm{eV}$ 付近に新たなピークが現れた。一方,

$\mathrm{Fe} 2 \mathrm{p}_{3 / 2}$ は最外表面では $712 \mathrm{eV}$ 付近にピークを認めた が,スパッタリングにともないピーク位置は低エネルギ 一側にシフトした。O 1s は最外表面では高エネルギー 側に肩状ピークをもつブロードなピークを $532 \sim 533 \mathrm{eV}$ 付近に認めた。スパッタリングにともない肩状ピークは 消失し，低ェネルギー側のシャープなピークが残った。

\section{4. 考察}

\section{1 高温純水中での腐食機構}

高温水中での酸化皮膜の成長機構に関しては, 主に脱 気アルカリ水中での炭素鋼を対象に調べられてきた。 Potter と $\mathrm{Mann}^{12), 13)}$ は, $300^{\circ} \mathrm{C}$ の濃厚水酸化ナトリウム 水溶液中で炭素鋼表面に 2 層構造の皮膜が形成されるこ とを認めた。この実験では銀あるいは銅のマーカーをあ らかじめ金属表面にめっきし, 酸化処理したのちマーカ 一が 2 層皮膜の中間位置に存在したことから，これらの 皮膜層が内方と外方に同時に成長したものと考えた。す なわち, 皮膜/金属界面では酸素を担った化学種の内方 拡散により酸化が進行し，同時に鉄イオンの外方拡散に より水/皮膜界面でも酸化物が析出し, 皮膜が形成され る。しかし, Bloom ら ${ }^{14)}$ は Potter らと同様の環境中で

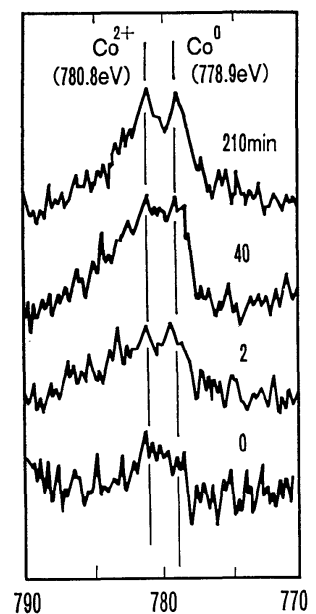

(a)

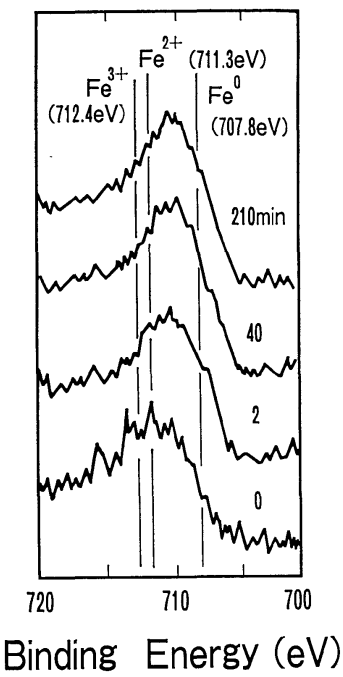

(b)

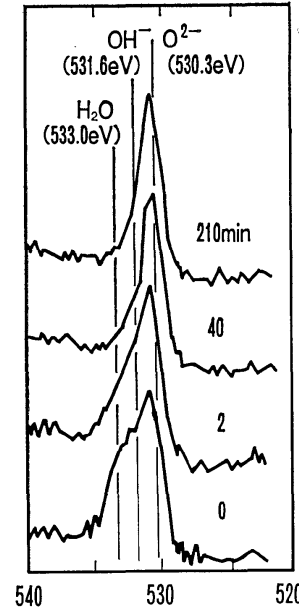

(c)

Fig. 8 XPS spectra of $2 \mathrm{p}_{3 / 2}$ level of $\mathrm{Co}, \mathrm{Fe}$ and $1 \mathrm{~s}$ level of 0 for oxide films on carbon steel exposed for $1000 \mathrm{~h}$ at $288^{\circ} \mathrm{C}, \mathrm{Ar}^{+}$sputtering time O-210 min; (a) Co, (b) $\mathrm{Fe}$, (c) O. 
一層構造の皮膜が形成されると報告した。さらに, 皮膜

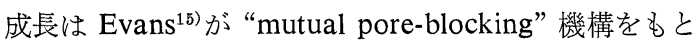
に導き出した対数則にしたがっていた。Berge ら ${ }^{16)}$ はこ の酸化機構の違いが, 皮膜中に存在する細孔内の水素濃 度分布の違いに基づくものであろらと考皇た。その考光 は次のようなものである。皮膜中で水素濃度勾配がある 場合，すなわち，腐食によって金属表面で形成された水 素が水側昿散する場合には，皮膜/金属界面で鉄酸化 物が形成される一方, 鉄イオンが外方に拡散する。しか 乙，皮膜内の各部に执いて酸化物と鉄イオンとの間には 平衡関係が成り立ち，鉄イオンは皮膜内で沈殿すること なく水/皮膜界面まで拡散し，そこで新たな皮膜を形成 する。その結果, 皮膜は厚い 2 層構造となる。一方, 水 素が金属側泣拡散し，皮膜中には水素濃度勾配ができな い場合には，生成した鉄イオンは直ちに皮膜/金属界面 で酸化物を形成する結果, 皮膜は薄い 1 層構造をとるこ とになる。以上に述べた皮膜成長機構は水素発生型腐食 の場合であるが, 酸素消費型腐食と考兄られる BWR 環 境汸いても似た考方方ができるであるう。

微量な金属イオンを含む溶液中に材料を浸漬した場 合，この金属イオンは皮膜の成長点に和いて皮膜内に取 り込末れ, 皮膜内濃度は乞の点に抢沙る溶液の濃度に比 例すると考兄られる。したがって，皮膜が水/皮膜界面 で外方に成長するとすれば，同界面の金属イオン濃度は バルク溶液の濃度に等しいため, 取り込まれた金属の皮 膜深さ方向の濃度分布は一定である。しかし，皮膜/金 属界面の金属イオン濃度は, 金属イオンの拡散が皮膜に よって妨げられるため皮膜成長にともなって減少する。 したがって, 皮膜深さ方向の濃度は単調に減少するであ ろう。

ところで, $\mathrm{Co}^{2+}$ イオンを注入しない水中で形成した 皮膜内でのコバルトの濃度分布は, 304 鋼では皮膜表面 方向にわずかに減少し，また炭素鋼では金属母材とほ洼 同じレベルにある17)。したがって，Fig. 4 及び 7 亿示し た皮膜内に郝けるコバルトの濃度分布の結果は, このコ バルトが水側から取り込まれたものでありまた 304 鋼 及び炭素鋼いずれの皮膜もその大半が皮膜/金属界面で 内方向に成長して拉り, 水/皮膜界面での外方向への成 長は小さく, Bloom タイプの 1 層構造をとっているこ とを示していると考光られる。

また，皮膜成長がいずれも対数則でよく表すことがで きることから, 腐食速度が皮膜中の細孔の残存率に比例 すると考觉た “mutual pore-blocking” 機構を適用で き, 新たに生成される酸化物は皮膜中の細孔を順次埋め ながら，皮膜を形成していくと考光られる。この現象は 言い換えると次のよらになる。鉄系酸化物の場合には, 酸化物の形成にともなら体積膨張率を示す Pilling- Bed- worth 比が 1 より大きい。したがって, 皮膜/金属界面で 金属表面にプレート状に形成した酸化物層には圧縮応力 が働き, き裂が生じる。その結果, 生成した酸化物結晶 甶々䎲成長するが，同時裂を生じた皮膜/金属界 面では新なな酸化物層が形成される。皮膜はこの繰り返 しによって成長していく。な和, 以上の考察は皮膜内の 金属分布の結果に基づくものであり，推定の部分も多い ことから，機構解明にはより一層の研究を必要とする。

\section{2 ステンレス鋼酸化皮膜の形態}

次に, BWR 環境で形成した 304 鋼の酸化皮膜中に拉 けるコバルト, 鉄, クロム, ニッケル及び酸素の存在状 態を推定した。

コバルト：皮膜最外表面の Co $2 \mathrm{p}_{3 / 2}$ スペクトルに現 孔た $781 \mathrm{eV}$ ピークは $\mathrm{CoO}$ 及び $\mathrm{CoFe}_{2} \mathrm{O}_{4}$ の $\mathrm{Co} 2 \mathrm{p}_{3 / 2}$ ピークの結合ェネルギー $(780.8 \mathrm{eV})$ と一致していた。し たがって，コバルトは $\mathrm{Co}^{2+}$ で皮膜中に存在していると 考兄られる。な扔，同じ環境で炭素鋼を浸漬した場合に 形成した皮膜をX線回折で調べたところ, $\mathrm{CoFe}_{2} \mathrm{O}_{4}$ が 検出された。したがって，304 鋼の場合もコバルトフェ ライトとして存在している可能性が強い。ところで, ス パッタリングを行った場合に, $779 \mathrm{eV}$ に表れたピーク

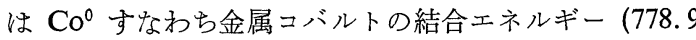
$\mathrm{eV)}$ と一致していた。このピークは $\mathrm{CoFe}_{2} \mathrm{O}_{4}$ 試薬をス パッタリングした場合にも検出されたことから，スパッ タリングにより, $\mathrm{Co}^{2+}$ が還元されたものであり $\mathrm{Co}^{2+}$ イオンが $\mathrm{Co}^{0}$ として析出したとは考光にくい。したが って，コバルトは皮膜のいずれの位置においても $\mathrm{Co}^{2+}$ で析出したと考兄られる。な拈，析出機構については水 熱合成反応等も考光ねばならず，今後の研究に待つとこ ろが大きい。

鉄：皮膜最外表面の $\mathrm{Fe} 2 \mathrm{p}_{3 / 2}$ スペクトルに現れた 712 $\mathrm{eV}$ ピークは, $\mathrm{Fe}^{2+}$ と $\mathrm{Fe}^{3+}$ の結合エネルギー(それぞ れ， $711.3 \mathrm{eV}$ 及び $712.4 \mathrm{eV})^{18)}$ の中間に位置している ことから, この 2 つ酸化状態の混成ピークと考兄られ る。スパッタリングによる低結合エネルギー側へのピー クのシフトはコバルトと同じ現象によるものであろう。

クロム: $\mathrm{Cr} 2 \mathrm{p}_{3 / 2}$ はスパッタリング後も $577 \mathrm{eV}$ に 単一ピークをもっていたが、これは $\mathrm{Cr}^{3+}(577.1 \mathrm{eV})^{18)}$ と一致している。また, このピーク面積はスパッタリン グとともに大きくなって叔り, 皮膜内層でク口ム濃度が 增していることがわかる。

ニッケル: Ni 2 $\mathrm{p}_{3 / 2}$ は計数感度が悪く, 皮膜最外表面 のピークは明瞭でないが, $857 \mathrm{eV}$ 付近のピークは $\mathrm{Ni}^{2+}$ $(856.5 \mathrm{eV})^{19)}$ と一致している。スパッタリングにより 現れた $854 \mathrm{eV}$ ピークは $\mathrm{Ni}^{0}(853.9 \mathrm{eV})^{18)}$ と一致してお り、コバルト，鉄と同じよらにスパッタリングにより $\mathrm{Ni}^{2+}$ が還元した結果と思われる。 
Table 4 Relative intensity of $\mathrm{O}^{2-}$ and $\mathrm{OH}^{-}$ signals in oxide films on Type 304 stainless steel exposed for $1,000 \mathrm{~h}$ at $288^{\circ} \mathrm{C}$.

\begin{tabular}{rcc}
\hline $\begin{array}{c}\text { Sputtering Time } \\
(\mathrm{min})\end{array}$ & $\mathrm{O}^{2-}$ & $\mathrm{OH}^{-}$ \\
\hline 0 & 0.49 & 0.51 \\
2 & 0.65 & 0.35 \\
40 & 0.70 & 0.30 \\
210 & 0.77 & 0.23 \\
\hline
\end{tabular}

酸素：皮膜最外表面で検出されたブロードなピークは 吸着した $\mathrm{H}_{2} \mathrm{O}(533.0 \mathrm{eV})^{20)}, \mathrm{OH}^{-}(531.6 \mathrm{eV})^{20)}$ 及び $\mathrm{O}^{2-}(530.3 \mathrm{eV})^{20)}$ の混成ピークと考えられる。この混成 ピークをそれぞれの結合ェネルギーで分離すると, 吸着 した $\mathrm{H}_{2} \mathrm{O}$ はスパッタリングとともに減少している。Table 4 は $\mathrm{OH}^{-}$と $\mathrm{O}^{2-}$ のピーク強度比である。この結果 は皮膜の内層で $\mathrm{O}^{2-}$ の存在比率が増していることを示 している。すなわち, 皮膜表面には水酸化物あるいはオ キシ水酸化物が存在するが, 内層では酸化物主体に変わ っていることを意味している。

次に, 鉄, クロム, ニッケル各元素の水系での状態を 電位-pH 図をもとに検討した。Indig ら ${ }^{21)}$ が求めた $274^{\circ} \mathrm{C}$ の純水中に和ける 304 鋼の腐食電位は, DO 200 $\mathrm{ppb}$ で $-150 \sim-50 \mathrm{mV}$ (SHE) にある。な拉, Leibo$v^{2} \mathrm{it}^{22)}$ が $288^{\circ} \mathrm{C}$ で測定した值もほぼこの範囲にある。こ の電位に打ける各元素の状態は, Chen ら ${ }^{23)}$ が算出した $300^{\circ} \mathrm{C}$ での電位-pH 図から推定される。中性 $\left(\mathrm{pH}_{300}=\right.$ 5.5) において, 鉄は $\mathrm{Fe}_{2} \mathrm{O}_{3}$, ニッケルは $\mathrm{NiO}$, クロムは $\mathrm{Cr}_{2} \mathrm{O}_{3}$ の安定域にある。この結果は金属単体一水の 2 元 系における平衡状態であるから, BWR の実環境である 合金一流動水系のような多元系でかつ非平衡な状態とは 当然異なってこよう。しかし, ある程度の推定は可能で, たとえば鉄の場合は中性条件で $\mathrm{Fe}_{2} \mathrm{O}_{3}$ 及び $\mathrm{Fe}_{3} \mathrm{O}_{4}$ とし ての酸化物安定電位は $-900 \sim+500 \mathrm{mV}$ (SHE) と広い 範囲にあり, 腐食にともなって大半が皮膜を形成し, 放 出量は少ないことが考えられる。この結果は本実験結果 とよく一致している。また, ニッケルの場合も中性では $-600 \mathrm{mV}$ (SHE) 以上と広い範囲に酸化物安定領域があ るが，酸化物中に 3 価金属として存在する領域は +100 $\mathrm{mV}$ (SHE) より貴な電位であり, BWR 環境では存在し にくいと思われる。な拉, 弱酸性条件では $\mathrm{Ni}^{2+}$ が安定 になることを考えると, 鉄よりはニッケルの放出率が大 きいことも推定され，このことは皮膜中の $\mathrm{Ni} / \mathrm{Fe}$ 比が母 材よりも小さいことを示している Table 3 の結果とも符 合する。クロムでは酸化物の安定電位は他の 2 金属に比 ベると低電位側にあり, $-1,300 \sim+100 \mathrm{mV}$ (SHE) であ
る。これは DO が低い場合にクロム酸化物が安定化して くることを示しており， $\mathrm{BWR}$ 環境では $\mathrm{CrO}_{4}{ }^{2-}$ あるい は $\mathrm{Cr}_{2} \mathrm{O}_{7}{ }^{2-}$ として溶出する可能性が大きい。また, ニッ ケルとは逆に弱アルカリ性条件で溶出しやすくなると考 えられる。以上の結果から, 304 鋼の皮膜は表面層には $\alpha-\mathrm{Fe}_{2} \mathrm{O}_{3}$ と水酸基を有する酸化物が存在するが，内層に 行くにしたがって $\mathrm{Fe}_{3} \mathrm{O}_{4}$ を主体とするスピネル型酸化 物 $\left(\mathrm{M}^{\mathrm{II}} \mathrm{O} \cdot \mathrm{M}^{\mathrm{III}}{ }_{2} \mathrm{O}_{3}\right)$ に変わっていると考えられる。 $\mathrm{M}^{\mathrm{II}}$ の位置は母材主要構成元素である鉄とニッケルが占める ほか, 炉水中の ${ }^{60} \mathrm{Co},{ }^{58} \mathrm{Co}$ 等の 2 価陽イオンも占める。 一方， M ${ }^{I I I}$ の位置は鉄とクロムが占めるが，クロムの割 合は内層ほど高くなる。また, 炉水中の ${ }^{51} \mathrm{Cr}$ もこの位置 を占める。な拉, ${ }^{51} \mathrm{Cr}$ は 6 価イオンとして炉水中に存在 するが，たとえば (3) 式に和ける左側への反応により 3 価に還元されて析出すると考觉られる。

$$
2 \mathrm{Cr}^{3+}+8 \mathrm{H}_{2} \mathrm{O}=2{ }^{51} \mathrm{CrO}_{4}{ }^{2-}+16 \mathrm{H}^{+}+6 \mathrm{e}^{-}
$$

\section{3 炭素鋼酸化皮膜の形態}

炭素鋼の腐食で顕著な特徵は, 初期の腐食速度は大き いが，その後の腐食が著しく抑制されていることにあ る。1,000 h 浸漬後の腐食状態の検討から，わずか $1 \%$ の 放出しか認められないことがこの特徵を裏付けている。 すなわら SEM の観察結果にみられるように, 皮膜が緻 密でその保護性は 304 鋼より大きいと考兄られる。ま た，蓄積したコバルトは $\mathrm{CoFe}_{2} \mathrm{O}_{4}$ で存在することがX 線回折により明らかとなった。次に，皮膜内に和ける元 素の存在形態をXPS による分析結果から推定した。

コバルト：皮膜最外表面の Co $2 \mathrm{p}_{3 / 2}$ スペクトルに 現れた $781 \mathrm{eV}$ ピークは $\mathrm{CoFe}_{2} \mathrm{O}_{4}$ の結合エネルギー $(780.8 \mathrm{eV})$ とよく一致しており, $\mathrm{X}$ 線回折の結果から もこのピークは $\mathrm{CoFe}_{2} \mathrm{O}_{4}$ であると考えられる。スパッ

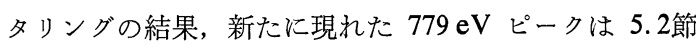
に述べたように $\mathrm{CO}^{0}$ に一致するが，これはスパッタリン グによって $\mathrm{Co}^{2+}$ が還元されたもので, コバルトは内層 に执いても $\mathrm{CoFe}_{2} \mathrm{O}_{4}$ としての及存在すると思われる。

鉄：皮膜最外表面の $\mathrm{Fe} 2 \mathrm{p}_{3 / 2}$ スペクトルに現れた $712 \mathrm{eV}$ ピークは $\mathrm{Fe}^{2+}$ と $\mathrm{Fe}^{3+}$ の混成ピークと考えられ る。またスパッタリングの影響でピークが低エネルギ

Table 5 Relative intensity of $\mathrm{O}^{2-}$ and $\mathrm{OH}^{-}$ signals in oxide films on carbon steel exposed for $1,000 \mathrm{~h}$ at $288^{\circ} \mathrm{C}$.

\begin{tabular}{rll}
\hline \hline $\begin{array}{c}\text { Sputtering Time } \\
(\mathrm{min})\end{array}$ & $\mathrm{O}^{2-}$ & $\mathrm{OH}^{-}$ \\
\hline 2 & 0.64 & 0.36 \\
40 & 0.70 & 0.30 \\
210 & 0.74 & 0.26 \\
\hline
\end{tabular}


一側にシフトしていることも 304 鋼の場合と同じであ る。

酸素: 皮膜最外表面では吸着した $\mathrm{H}_{2} \mathrm{O}(533.0 \mathrm{eV})^{20)}$ が存在した。ピーク分離の結果, Table 5 に示すように 304 鋼の場合と同様, 内層方向で $\mathrm{OH}^{-}$の存在比率が減 り, $\mathrm{O}^{2-}$ の比率が高くなっている。これは 304 鋼の場合 之同様, 外層では水酸化物あるいはオキシ水酸化物が存 在するが，内層は酸化物主体であることを示している。

炭素鋼では鉄-水系の電位-pH 図から, BWR 環境に おける腐食状態の推定が 304 鋼よりも容易である。

Indig ${ }^{24)}$ が求めた $274^{\circ} \mathrm{C}$ での腐食電位は DO $200 \mathrm{ppb}$ でー130 mV (SHE) で, 304 鋼と同程度の值である。し たがって, 鉄は $\mathrm{Fe}_{2} \mathrm{O}_{3}$ の安定域にあり, $\mathrm{X}$ 線回折結果 並びに腐食にともなら放出量が極めて少ないといら事実 ともよく一致する。炭素鋼の皮膜は表面が $\alpha-\mathrm{Fe}_{2} \mathrm{O}_{3}$ と水 酸基を有する酸化物で構成され, 内層では $\mathrm{Fe}_{3} \mathrm{O}_{4}$ 主体に 変化すると考えられる。

\section{5. 結 言}

BWR 環境に打ける鉄鋼材料の腐食と, それにともな ら酸化皮膜の成長及び微量のコバルトイオンの蓄積機構 について検討した結果，次の結論を得た。

（1）皮膜は皮膜/金属界面で内方向に成長し，1,000 $\mathrm{h}$ 浸漬に拈ける腐食生成物の放出率は 304 鋼で $12 \%$, 炭素鋼で $1 \%$ と小さい。

(2) 304 鋼の皮膜は $\mathrm{Fe}_{3} \mathrm{O}_{4}$ を主体とするスピネル型

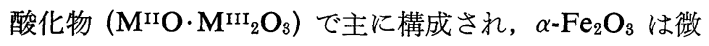
量で外層のみに存在する。クロムは放出率が大きく, 皮 膜は主に鉄とニッケルから構成される。水中に溶存する コバルトイオンは皮膜/金属界面でスピネル型酸化物の $\mathrm{M}^{\mathrm{II}}$ の位置に析出し, 濃度は皮膜内方向に単調減少す る。また, 皮膜表面には水酸化物あるいはオキシ水酸化 物が存在し, 内層は酸化物主体である。

(3) 炭素鋼の皮膜は $\mathrm{Fe}_{3} \mathrm{O}_{4}, \alpha-\mathrm{Fe}_{2} \mathrm{O}_{3}$ で構成され, 皮膜表面には水酸化物あるいはオキシ水酸化物が存在 し, 内層は酸化物主体である。また、コバルトイオンは 304 鋼と同様の蓄積機構に基づき, $\mathrm{CoFe}_{2} \mathrm{O}_{4}$ として析出 する。

(Received October 25, 1986)

\section{文献}

1) 例觉ば, 大角克巳, 鶴岡良造, 内田俊介, 泉谷雅 清：日立評論, 68, 319 (1986).
2) E. G. Brush \& W. L. Pearl: Corrosion, 28, 129 (1972).

3) D. C. Vreeland, G. G. Gaul \& W. L. Pearl: Corrosion, 17, 269 (1961).

4）伊藤伍郎, 清水義彦, 佐藤俊司：防食技術, 18, 345 (1969).

5) 岩堀 徹, 加藤俊二, 和田邦久, 水野孝之: 防食 技術, 32, 580 (1983).

6) M. Kitamura, Y. Ozawa \& S. Uchida: Int. Symp. on Environmental Degradation of $\mathrm{Ma}$ terials in Nuclear Power Systems-Water Reactors, No. 22, South Carolina (1983).

7) 前川立夫, 香川 優, 中島恒雄: 日本金属学会 誌, 35, 1213 (1967).

8) T. Honda, M. Izumiya, A. Minato, K. Ohsumi \& H. Matsubayashi: Nucl. Technol., 64, 35 (1984).

9) T. Honda, A. Minato, K. Ohsumi \& H. Matsubayashi: Nucl. Technol., 65, 438 (1984).

10) G. Romeo: Nucl. Technol., 63, 110 (1983).

11) D. H. Lister: Nucl. Sci. Eng., 59, 406 (1976).

12) E. C. Potter \& G. M. W. Mann: Proc. 1st Int. Congr. on Metallic Corrosion, 417, London (1961).

13) E. C. Potter \& G. M. W. Mann: Proc. 2nd Int. Congr. on Metallic Corrosion, 872, New York (1963).

14) M. C. Bloom, G. N. Newport \& W. A. Fraser: J. Electrochem. Soc., 111, 1343 (1964).

15) U. R. Evans: "The Corrosion and Oxidation of Metals," Edward Arnold Ltd. (1960).

16) Ph. Berge, C. Ribon \& P. S. Paul: Corrosion, 33, 173 (1977).

17) T. Honda, A. Minato, K. Ohsumi \& H. Matsubayashi: To be published in Corrosion.

18) D. T. Harvey \& R. W. Linton: Anal. Chem., 53, 1684 (1981).

19）杉本克久, 岸 興作, 池田重良, 沢田可信: 日本 金属学会誌, 38, 54 (1974).

20) M. Datta, H. J. Mathieu \& D. Landolt: $J$. Electrochem. Soc., 131, 2484 (1984).

21) M. E. Indig \& J. E. Weber: Corrosion, 41, 19 (1985).

22) J. Leibovitz: EPRI NP-2524, Electric Power Research Institute (July 1982).

23) C. M. Chen, K. Aral \& G. J. Theus: EPRI $N P$-3137, Electric Power Research Institute (June 1983).

24) M. E. Indig: "BWR Environmental Cracking Margins for Carbon Steel Piping," EPRI 1st Semiannual Progress Report, Electric Power Research Institute (1979). 